\title{
Synthesis of Penicillin V
}<smiles>CC(C)C(N)C(=O)O</smiles>

( \pm )-Valine

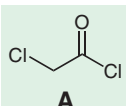

A<smiles>CC(C)C(NC(=O)CCl)C(=O)O[Na]</smiles><smiles>CC1=NC(=C(C)C)C(=O)O1</smiles>

1. $\mathrm{H}_{2} \mathrm{~S}, \mathrm{Na}, \mathrm{MeOH}$ $0^{\circ} \mathrm{C}$ to r.t. 2. $\mathrm{H}_{2} \mathrm{O}, 90^{\circ} \mathrm{C}$<smiles>CC(=O)NC(C(=O)O)C(C)(C)S</smiles><smiles>CC1(C)SC(C)(C)N(CF)[C@H]1C(=O)O</smiles><smiles>CC1(C)SC(C)(C)N(C=O)C1C(=O)O</smiles><smiles>CC(C=O)CC1(C)NC(C(=O)O)C(C)(C)S1</smiles>

1. $\mathrm{N}_{2} \mathrm{H}_{4} \cdot \mathrm{H}_{2} \mathrm{O}, \mathrm{H}_{2} \mathrm{O}$

1,4-dioxane, $13^{\circ} \mathrm{C}$ to r.t.

2. conc $\mathrm{HCl}, \mathrm{AcOH}$<smiles>CC(C)(C)OC(=O)[C@H](Nc1ccccc1)[C@H]1N[C@H](C(=O)O)C(C)(C)S1</smiles>

$13^{\circ} \mathrm{C}$ to r.t.

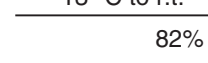

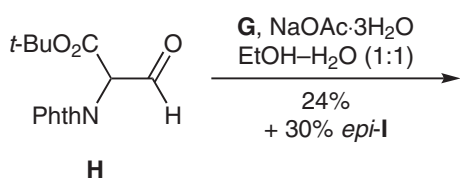

Synthesis of Natural

Products and

Potential Drugs

\section{Key words}

B-lactam antibiotic

penicillamine

penicilloic acid

penicillin $\mathbf{V}$

modified

Erlenmeyer-Plöchl azlactone synthesis

carbodiimide

coupling

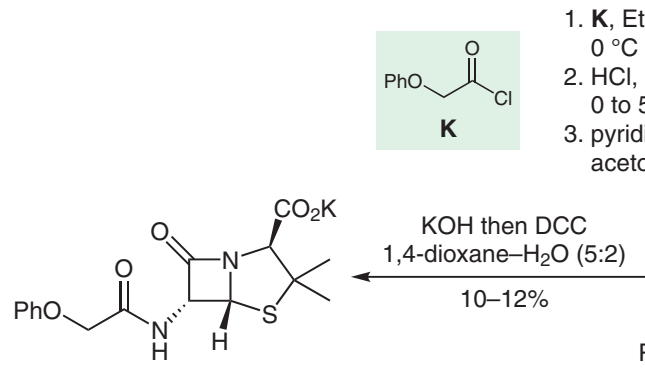

(+)-Penicillin V potassium salt

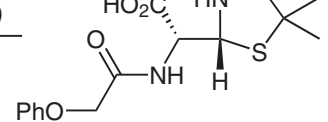

Significance: The penicillins constitute a family of $\beta$-lactam antibiotics which were first discovered in 1928 by Alexander Fleming. The lability of the amide bond is responsible for their remarkable bioactivity. The formation of this bond posed a major challenge in early synthetic studies towards penicillins. Having previously invented carbodiimide coupling agents, Sheehan and co-workers achieved the first total synthesis of penicillin V in 1957.
Comment: Racemic valine was efficiently transformed into $\mathrm{N}$-acetylpenicillamine (D). Resolution of formamide rac-F using brucine followed by hydrolysis afforded (-)-penicillamine hydrochloride (G). Condensation with aldehyde $\mathbf{H}$ afforded thiazolidine I; side-product epi-I could be converted into I employing pyridine-induced epimerization. Removal of protecting groups and installation of the phenoxyacetyl side chain furnished penicilloic acid $\mathbf{L}$. Subsequent construction of the central amide bond was achieved with DCC under basic conditions to give the potassium salt of penicillin $\mathrm{V}$. 